\title{
Chronic arsenicosis
}

\author{
Dibyendu Bikash Bhanja, ${ }^{1}$ Abheek Sil, ${ }^{1}$ Subhra Sankar Sen, ${ }^{2}$ Atanu Chandra (i) ${ }^{3}$
}

'Dermatology, Venereology, Leprosy, RG Kar Medical College and Hospital, Kolkata, West Bengal, India

${ }^{2}$ Internal Medicine, Midnapore Medical College and Hospital, Midnapore, West Bengal, India ${ }^{3}$ Internal Medicine, RG Kar Medical College and Hospital, Kolkata, West Bengal, India

\section{Correspondence to}

Dr Atanu Chandra; chandraatanu123@gmail.com

Accepted 6 July 2021

\section{DESCRIPTION}

A 40-year-old woman hailing from a village in eastern India presented with a 6-year history of generalised asymptomatic pigmentary skin alterations. Her medical history was significant for diabetes mellitus for which she was on oral hypoglycaemic agent for past 4 years. She had no history of any pre-existing dermatoses. She reported that some of her village neighbours also had similar cutaneous ailments. None of her immediate family members were affected. The primary source of drinking water in her village was a deep tube well. She had previously been treated by the village quack without any improvement. Examination revealed multiple, discrete, guttate hypopigmented macules $(2-4 \mathrm{~mm})$ symmetrically dispersed over a hyperpigmented background that involved the trunk and extremities giving a 'raindrop' appearance (figure 1). Few well-demarcated brownish scaly plaques with irregular border were noted over back, abdomen and dorsum of right hand. Histopathology of one such excised lesion reported Bowen's disease. Multiple keratotic papules over palms and soles with gritty sensation on palpation were also noted (figure 1B). Other mucocutaneous sites were unaffected. Systemic examination did not reveal any abnormality. Basic laboratory investigations only revealed mild anaemia. The clinical diagnosis of chronic arsenicosis was further established by markedly elevated arsenic levels in hair, nail and drinking water samples. She was counselled to avoid arsenic-contaminated tube well water. Palmoplantar hyperkeratosis substantially flattened over 3 months with regular use of keratolytic ointment. Topical 5\% 5-fluorouracil for lesions of bowen's disease led to improvement. No new-onset cutaneous premalignant or malignant transformation was noted on routine follow-ups.

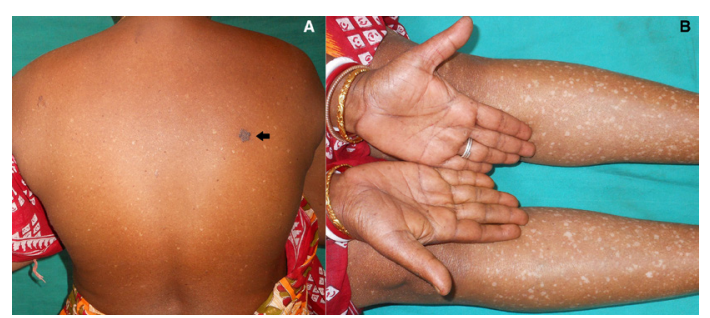

C) BMJ Publishing Group Limited 2021. No commercial re-use. See rights and permissions. Published by BMJ.

To cite: Bhanja DB, Sil A, Sen SS, et al. BMJ Case Rep 2021;14:e244071 doi:10.1136/bcr-2021244071
Figure 1 Multiple, discrete, small, hypopigmented macules symmetrically dispersed over hyperpigmented background of trunk resembling 'raindrop' appearance; lesion of Bowen's disease to be noted (black arrow) (A); multiple, discrete, small, hypopigmented guttate macules symmetrically dispersed over lower extremity and numerous keratotic papules (arsenical keratoses) over palms (B).
Although mostly prevalent in endemic regions, arsenicosis has emerged as a global public health concern. ${ }^{1}$ This chronic multisystem disorder has been defined by WHO working group as a 'chronic health condition arising from prolonged ingestion (not less than 6 months) of arsenic above a safe dose, usually manifested by characteristic skin lesions, with or without involvement of internal organs. ${ }^{2}$ Exposure occurs through drinking water, agricultural uses, ore mining and traditional medicinal preparations. Cutaneous lesions are the most common manifestation in arsenicosis patients. Among all dermatological manifestations, pigmentary changes are the earliest to appear. This can be diffuse, localised (patchy pigmentation), finely freckled, 'raindrop' pattern or depigmentation that is particularly pronounced on the trunk and extremities. Blotchy pigmentation may also involve mucous membranes such as the under surface of the tongue or buccal mucosa. Arsenical hyperkeratosis is characterised by thick, hard, rough hyperkeratotic skin especially of the palm and sole. ${ }^{2}{ }^{3}$ Cutaneous malignancies (Bowen's disease, squamous cell carcinoma, basal cell carcinoma and Merkel cell carcinoma) develop after many years of arsenic exposure. ${ }^{4}$ Apart from cutaneous manifestation, chronic arsenic toxicity may be associated with peripheral vascular disease (Blackfoot disease), hypertension, ischaemic heart disease, non-cirrhotic portal hypertension, peripheral neuropathy and diabetes mellitus. ${ }^{5}$

Differential diagnoses of cutaneous dypigmentation include dyschromatosis symmetrica hereditaria, dyschromatosis universalis hereditaria, amyloidosis cutis dyscromica, generalised Dowling-Degos disease and Darier's disease. Arsenical keratosis ought to be differentiated from verruca vulgaris, punctate palmoplantar keratoderma, punctate porokeratosis,

\section{Learning points}

- Prolonged ingestion of arsenic above a safe dose (more than $0.01 \mathrm{mg} / \mathrm{L}$ ) for more than 6 months leads to the development of chronic arsenicosis. The distinctive 'raindrop' pattern pigmentation is usually more pronounced on the trunk and extremities.

- Cutaneous malignancies (Bowen's disease, squamous cell carcinoma, basal cell carcinoma and Merkel cell carcinoma) develop after many years of arsenic exposure.

- Longitudinal follow-up is of utmost importance for early detection and management of cutaneous malignancies and systemic complications in chronic arsenicosis patients. 
porokeratotic eccrine ostial and dermal duct nevus, Cole's disease and punctate keratosis of palmoplantar creases. These entities can be ruled out based on thorough clinical examination, supplemented with relevant investigations as needed. The distinctive 'raindrop pigmentation' associated with palmoplantar hyperkeratosis enable the physicians to promptly diagnose chronic arsenicosis and ensure long-term follow-ups for early detection of cutaneous malignancies and systemic complications.

Contributors DBB and AS prepared the manuscript with adequate planning and execution; they also collected data regarding the patient. AS and SSS were the direct care givers to the patient, who managed the case actively and collected relevant data on investigations with equal contributorship. AC helped in detailed supervision, final output and the review of literature regarding the manuscript. DBB supervised the entire management of the patient and has actively contributed in editing the manuscript. All authors are in agreement to be accountable for all aspects of the work in ensuring that questions related to the accuracy or integrity of any part of the work are appropriately investigated and resolved.
Funding The authors have not declared a specific grant for this research from any funding agency in the public, commercial or not-for-profit sectors.

Competing interests None declared.

Patient consent for publication Obtained.

Provenance and peer review Not commissioned; externally peer reviewed.

\section{ORCID iD}

Atanu Chandra http://orcid.org/0000-0002-3809-8926

\section{REFERENCES}

1 Das NK, Sengupta SR. Arsenicosis: diagnosis and treatment. Indian I Dermato/ Venereol Leprol 2008;74:571-81.

2 Sil A, Bhanja DB, Panigrahi A, et al. Palmoplantar keratosis and raindrop pigmentation in chronic arsenicosis. QJM 2020;113:584-5.

3 Kadono T, Inaoka T, Murayama N, et al. Skin manifestations of arsenicosis in two villages in Bangladesh. Int J Dermatol 2002;41:841-6.

4 Panigrahi A, Chakraborty S, Sil A. Arsenical squamous cell carcinoma. Am J Med Sci 2021:361:e45.

5 Rahman MM, Chowdhury UK, Mukherjee SC, et al. Chronic arsenic toxicity in Bangladesh and West Bengal, India--a review and commentary. J Toxicol Clin Toxicol 2001;39:683-700

Copyright 2021 BMJ Publishing Group. All rights reserved. For permission to reuse any of this content visit

https://www.bmj.com/company/products-services/rights-and-licensing/permissions/

BMJ Case Report Fellows may re-use this article for personal use and teaching without any further permission.

Become a Fellow of BMJ Case Reports today and you can:

- Submit as many cases as you like

Enjoy fast sympathetic peer review and rapid publication of accepted articles

Access all the published articles

Re-use any of the published material for personal use and teaching without further permission

\section{Customer Service}

If you have any further queries about your subscription, please contact our customer services team on +44 (0) 2071111105 or via email at support@bmj.com.

Visit casereports.bmj.com for more articles like this and to become a Fellow 